\title{
NATURAL REGENERATION IN ANTHROPOGENIC ENVIRONMENTS DUE TO AGRICULTURAL USE IN THE CERRADO, UBERABA, MG, BRAZIL
}

\author{
REGENERAÇÃO NATURAL EM AMBIENTES ANTROPIZADOS POR USOS \\ AGRÍCOLAS NO CERRADO, UBERABA, MG, BRASIL
}

\section{Gilsonley Lopes dos SANTOS ${ }^{1}$; Marcos Gervasio PEREIRA ${ }^{2}$; Rafael Coll DELGADO ${ }^{3}$; José Luiz Rodrigues TORRES ${ }^{4}$}

1. Estudante de doutorado, Instituto de Florestas - UFRRJ, Seropédica, RJ, Brasil; 2. Universidade Federal Rural do Rio de Janeiro, Instituto de Agronomia, Departamento de Solos, Seropédica, RJ, Brasil; 3. Universidade Federal Rural do Rio de Janeiro, Instituto de Florestas, Departamento de Ciências Ambientais, Seropédica, RJ, Brasil; 4. Instituto Federal do Triângulo Mineiro, Uberaba, MG, Brasil.

\begin{abstract}
Evidence of environmental impact on the Cerrado is characterised by the presence of large homogeneous pastures and agricultural areas, with the presence of very fragmented and scattered forest fragments. When these areas are abandoned due to low productivity, natural regeneration begins, which is influenced by environmental factors. The goal of the present study was to evaluate the forest cover temporal dynamics in anthropogenic areas and the influence of climate on natural regeneration in the Cerrado. The study site was an anthropogenic area that has been protected against the entrance of domestic animals and agriculture since 2002. Environments were identified, and natural regeneration dynamics were analysed by the use of vegetation indices calculated from satellite images. Statistical analysis Non-parametric Mann-Kendall was used to check the trend of the rain and the Normalized Difference Vegetation Index, multivariate analysis to verify the correlations and groups between the years of occurrence of El Niño and La Niña and the values of Normalized Difference Index. Natural regeneration in the Cerrado increased over time and was positively correlated with rainfall incidence. The process of recovery of degraded areas by natural regeneration technique proved efficient in the Cerrado, however, natural regeneration is negatively influenced by the weather phenomenon El Niño.
\end{abstract}

KEYWORDS: Savannah. Vegetation index. Climate. Resilience.

\section{INTRODUCTION}

Cerrado is the second largest Brazilian biome. It covers 207 million hectares, which corresponds to $25 \%$ of the Brazilian territory and approximately $4 \%$ of the world's tropical regions. It is considered to be a hotspot of biodiversity and a potential food-producing region in Brazil (MYERS et al., 2000, BAYER et al., 2004, BRAZ et al., 2010). However, part of its natural vegetation has been removed to establish agricultural crops and other agricultural activities, which has resulted in the formation of very sparse and fragmented vegetation remnants (KLINK; MACHADO, 2005, SILVA et al., 2006).

Currently, the large homogeneous pastures and agricultural areas found in the Cerrado are evidence of environmental impact. Natural regeneration can occur in those areas when they are abandoned due to low productivity (DURIGAN et al., 2011). Natural regeneration begins when seeds arrive and germinate and plants become established under the influence of different environmental factors, i.e., soil, topography, rainfall and temperature (ALMEIDA et al., 2005).

Vegetation restoration in anthropogenic environments is easier when the areas present natural regeneration potential. If regeneration capacity is lost, it becomes necessary to reintroduce plant species (DURIGAN et al., 2011). Vegetation dynamics in anthropogenic environments undergoing natural regeneration can be evaluated using vegetation indices such as the Normalized Difference Vegetation Index (NDVI), which can be used to study and evaluate changes in vegetation structure and expansion (PAVANELII; GUIMARÃES, 2014).

Geotechnical methods, which are used to calculate vegetation indices, are fundamental tools in studies of forests undergoing regeneration (RESENDE et al., 2015) and work well for monitoring and identifying different landscape vegetation features (CANDIDO et al., 2015). The Cerrado vegetation indices are affected by climate conditions. Rainfall directly affects plant physiological processes (BARBOSA et al., 2015; DELGADO et al., 2012) and has been reported to be correlated with NDVI in forest environments undergoing regeneration (GURGEL et al., 2003).

Rainfall in South America is associated with the El Niño and La Niña phenomena, which cause decreased or increased rainfall, respectively, and decreased or increased NDVI (JACÓBSEN et al., 2004; GRIMM et al., 2000) due to variations in the 
vegetation biomass of forest ecosystems (MOHAMED et al., 2015). The goal of the present study was to evaluate the forest cover temporal dynamics in anthropogenic areas and the influence of climate on natural regeneration in the Cerrado.

\section{MATERIAL AND METHODS}

\section{Study area}

The study was performed in a hydrographic microbasin located at the Federal Institute of Minas Gerais Triangle (Instituto Federal do Triângulo Mineiro - IFTM) Uberaba Campus, municipality of Uberaba, state of Minas Gerais (MG), Unit I of the Federal Institute of Technological Education (Instituto Federal de Educação Tecnológica - IFET), $23 \mathrm{~K}$ zone, which is located between $19^{\circ} 39^{\prime} 31.85^{\prime}$ ', and $19^{\circ} 40^{\prime} 2.38^{\prime \prime} \mathrm{S}$ and $47^{\circ} 57^{\prime} 54.21^{\prime \prime}$ and $47^{\circ} 57^{\prime} 12.983^{\prime \prime} \mathrm{W}$ and has an altitude between 740 and $810 \mathrm{~m}$. The region's soil is predominantly Red Dystrophic Latosol (Embrapa, 2006); however, Red Latosol, Yellow-Red Latosol, Petric Plinthosol, Fluvic Cambisol and Gleysol (Haplic and Melanic) were identified in the experimental area, which is part of the Arenitic-Basaltic Plateau of the Paraná river basin (COUTINHO et al., 2008).

The region's climate is $A w$ according to the Köppen (1948) climate classification: hot tropical with cold and dry winters. The Minas Gerais Triangle (Triângulo Mineiro) presents a rainy season from October until March or April and annual rainfall between $1300 \mathrm{~mm}$ and $1700 \mathrm{~mm}$. The annual average air relative humidity varies between $70 \%$ and $75 \%$, with a maximum of $81 \%$ and a minimum of 52\% (INMET, 2015).

The microbasin has a total area of 136 hectares and had been variously used for agricultural production until the end of 2001. In 2002, an area of approximately 40 hectares was fenced and protected against the entrance of domestic animals, especially cows and horses, and crop cultivation (TORRES; FABIAN, 2006). The area has been undergoing natural regeneration since that time.

The landscape of the hydrographic microbasin wherein the study area lies has been significantly changed by anthropic actions. The following types of soil use and occupation are found in the study area: infrastructures, farming, pastures, forestry, riparian forest, Cerrado, fallow lands, rubber tree plantations, vegetable gardens and sugarcane plantations (TORRES; FABIAN, 2006).

\section{Satellite images}

The satellite images were acquired by the Thematic Mapper (TM) sensor onboard Landsat 5 satellite from 2003 to 2010 and by the RapidEye multispectral pushbroom imager from 2011 to 2013 (a total of 11 years) and were obtained from the websites of the National Institute of Space Research (Instituto Nacional de Pesquisas Espaciais - INPE) and the Ministry of Environment (Ministério do Meio Ambiente - MMA). Images acquired during winter were selected due to the lower amount of cloud cover, which affects image quality and processing.

The images acquired by the TM sensor were processed by conducting radiometric and reflectance calibration for geometric distortion correction and noise removal using the ERDAS IMAGINE 2014 software package and corrected for a series of factors, i.e., atmospheric transparency and the optical and electronic characteristics of the sensor, using the equation by Markham \& Baker (1987) and part of the Surface Energy Balance Algorithms for Land (SEBAL) algorithm (ALLEN et al., 2002).

\section{Identification of Environments Undergoing Natural Regeneration}

Environments undergoing natural regeneration were identified using NDVI, which is a sensitive indicator of the presence of green vegetation. NDVI is calculated as the difference between the near-infrared $\left(\rho_{\mathrm{IV}}\right)$ and red $\left(\rho_{\mathrm{V}}\right)$ reflectance values divided by their sum (ROUSE et al., 1973, 1974):

$$
N D V I=\frac{\rho_{V V}-\rho_{V}}{\rho_{I V}+\rho_{V}},
$$

where,

$\rho_{I V}$ is the near-infrared band $(0.7-1.3 \mu \mathrm{m})$, and $\rho_{V}$ is the red band $(0.6-0.7 \mu \mathrm{m})$.

Based on the NDVI values for each image, incursions were performed in the study area to determine in which environments natural regeneration had occurred and/or was occurring. The images and environmental factors were processed using ArcGis 10.2. The natural regeneration temporal dynamics indicated by variations in NDVI were correlated with rainfall and the occurrence of $E l$ Niño and La Niña to understand the effects of environmental factors on the regeneration of the Cerrado.

Information on the occurrence of El Niño and La Niña was obtained from the National Oceanic and Atmospheric Administration (NOAA) 
database, which was accessed on 01/06/2015 (www.cpc.noaa.gov/products/analysis_monitoring).

\section{Meteorological Variables}

Monthly rainfall values were obtained from the Conventional Meteorological Station (Estação Meteorológica Convencional - EMC) of Uberaba, MG (code OMM: 83577) and were made available by the National Institute of Meteorology (Instituto Nacional de Meteorologia - INMET) (2003 - 2013). Following a preliminary data analysis, the annual and seasonal (dry and rainy season) average rainfall amounts were calculated for each year.

\section{Data analysis}

The NDVI and rainfall time series were subjected to a non-parametric Mann-Kendall's test (MANN, 1945; KENDALL, 1975). The MannKendall's test Z statistic $(\alpha=0.05)$ allows the acceptance of the null hypothesis $\mathrm{H}_{0}$ (the data are randomly ordered and there is no trend) or its rejection in favour of $\mathrm{H}_{1}$ (there is an increasing or decreasing trend). A positive $\mathrm{Z}$ statistic $(\mathrm{Z}>0)$ indicates an increasing trend, and a negative $Z$ statistic $(Z<0)$ indicates a decreasing trend.

The dependence of NDVI on rainfall was evaluated by performing a Simple Linear
Regression analysis of the relation between the NDVI time series and the annual and seasonal rainfall series and by analysing the significance of the correlation coefficients. A Two Step Cluster analysis was performed using the data of the occurrence of El Niño and La Niña and the NDVI values for the respective years. All of the statistical analyses were performed using the $R$ 3.2.1 and SPSS 15.0 software packages.

\section{RESULTS AND DISCUSSION}

The significant increases in NDVI observed in environments undergoing regeneration, expansion of the forest cover and changes in the vegetation structure indicated the occurrence of natural regeneration in the study area (Figure 1). The annual average NDVI increase of 0.015 and the average NDVI of 0.51 at the end of the study period indicates that the 11-year period of protection against domestic animal entrance, fires and agricultural exploration in the studied anthropogenic environments was sufficient for regeneration to occur naturally.
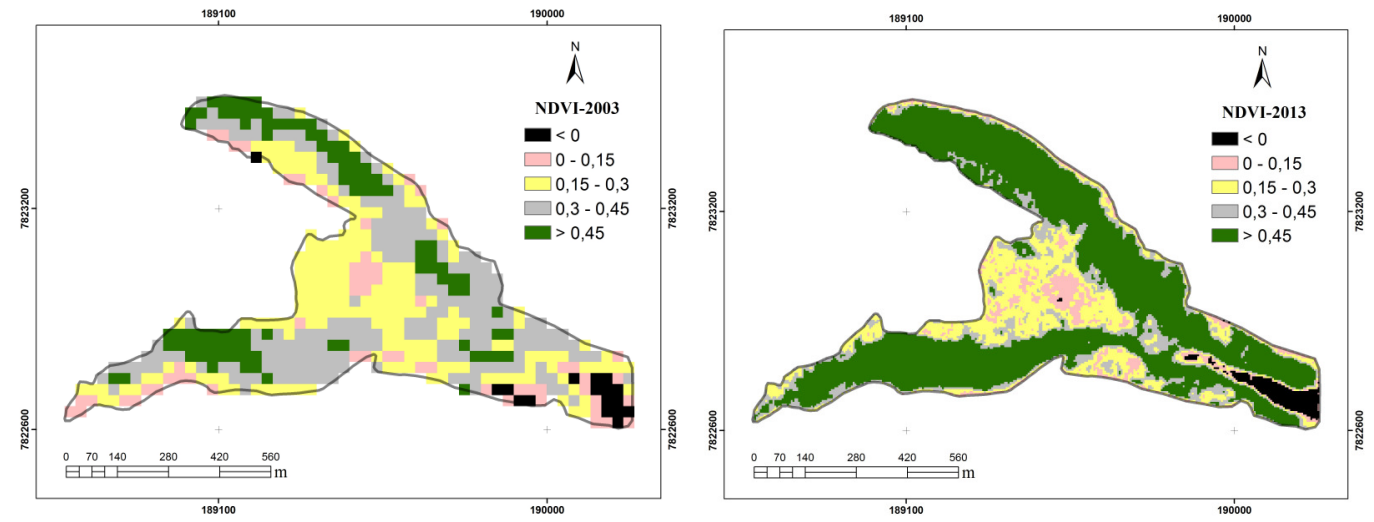

Figure 1. NDVI temporal dynamics during natural regeneration in the vegetation at IFTM.

Some studies of protected Cerrado areas have found a tendency for vegetation with lower biomass and open vegetation to be replaced by denser and closed vegetation that eventually become Cerradão (PAVANELII; GUIMARÃES, 2014; PINHEIRO; DURIGAN, 2009). NDVI is a biophysical parameter that allows the efficient study, evaluation and quantification of relative trends in vegetation dynamics because it allows the identification of changes in the expansion of vegetation and structure in protected environments (PAVANELII; GUIMARÃES, 2014).

Natural regeneration in the study area increased over time, and the positive correlation coefficient was greater than $60 \%$ (Figure 2). This was due to vertical and horizontal vegetation increases when compared to the vegetation present in 2002, when the area became protected, and by the appearance of trees and bushes as natural regeneration progressed.

Vegetation indices are important tools for the study of anthropogenic forest environments undergoing regeneration, specifically for the evaluation of variations in vegetation structure and the expansion of vegetation in regenerated areas (RESENDE et al., 2015). However, vegetation indices may be affected by environmental factors such as soil type, relief and rainfall and by the 
spatial and temporal resolutions of the sensors and platforms, which may interfere with the identification and analysis of vegetation cover (BECERRA et al., 2007). However, the use of high spatial resolution images has shown good results for monitoring of environments undergoing natural regeneration and allows the successful identification of different ecosystem features (CANDIDO et al., 2015).
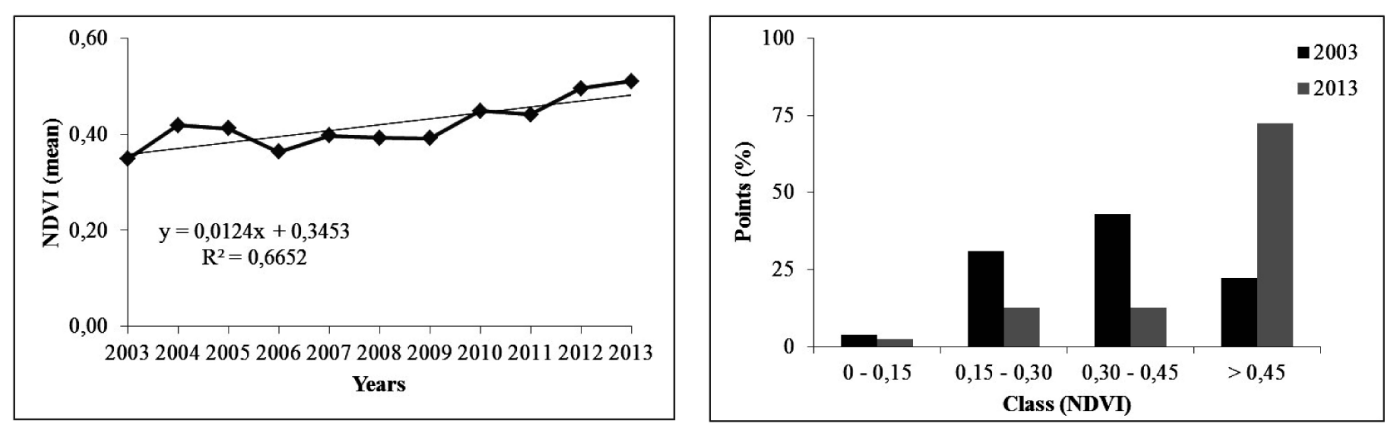

Figure 2. Temporal variations in NDVI as natural regeneration progressed in the Cerrado.

Biophysical (vegetation indices) and physical (rainfall and temperature) parameters have been used to identify and quantify forest environments undergoing regeneration. Rainfall has been observed to be a factor that strongly influences vegetation indices (BARBOSA et al., 2015; MOHAMED et al., 2015; LOPES et al., 2010). In the present study, statistically significant relationships were observed between NDVI and time ( $p=0.029)$ and rainfall $(p=0.042)$ during the dry season (Table 1). This indicates that rainfall is a determining environmental factor for natural regeneration in the Cerrado.

Table 1. Trend analysis using the Mann-Kendall test.

\begin{tabular}{cccccc}
\hline \multirow{2}{*}{ Statistical parameters } & \multirow{2}{*}{ NDVI } & \multirow{2}{*}{ P-annual } & \multicolumn{3}{c}{ NDVI } \\
\cline { 5 - 6 } & & & P-annual & P-dry & P-rainy \\
\hline $\mathrm{Z}$ & 0.527 & -0.037 & -0.183 & 0.491 & -0.2 \\
p-value & 0.029 & 0.938 & 0.482 & 0.043 & 0.436 \\
\hline
\end{tabular}

Legend: $\mathrm{P}=$ rainfall $(\mathrm{mm}) ; \mathrm{Z}=$ Mann-Kendall test statistic.

Barbosa et al. (2015) performed a similar study in the Cerrado and concluded that rainfall was the factor that most strongly determined variations in vegetation growth. Rainfall directly influences plant physiological processes, and the vegetation cover may increase or decrease depending on the occurrence or absence of rainfall, respectively.
A regression analysis was performed to better understand the relation between natural regeneration and rainfall. Significant regression coefficients were obtained for both the dry $(p$ $<0.10)$ and rainy seasons $(p<0.05)$, which indicate that rainfall explained the natural regeneration dynamics for both seasons. However, higher regression coefficients were observed for the rainy season (Table 2).

Table 2. Simple linear regression analysis

\begin{tabular}{cccc}
\hline \multirow{2}{*}{ Statistical parameters } & \multicolumn{3}{c}{ NDVI } \\
\cline { 2 - 4 } & P-annual & P-dry & P-rainy \\
\hline $\mathrm{R}^{2}$ - Multiple & 0.200 & 0.323 & 0.423 \\
$\mathrm{R}^{2}$-Fitted & 0.111 & 0.248 & 0.359 \\
Standard error & 0.048 & 0.044 & 0.040 \\
p-value & 0.168 & 0.068 & 0.030 \\
\hline
\end{tabular}

Legend: $\mathrm{P}=$ rainfall $(\mathrm{mm})$ 
Mohamed et al. (2015) evaluated the global trend in the variation of vegetation in response to climate variations and observed that higher vegetation biomass was directly related to higher

Because NDVI depends on climate conditions, it has been correlated with the occurrence of El Niño and La Niña. Because these phenomena cause increases or decreases in rainfall incidence and climate conditions that may be favourable or unfavourable to natural regeneration, they have been reported to directly influence vegetation dynamics in forest ecosystems (JACÓBSEN et al., 2004; GRIMM et al., 2000).

In the present study, the Two Step Cluster analysis identified two homogeneous clusters for NDVI depending on the occurrence of El Niño and La Niña, which indicated that the pattern of natural rainfall. However, other factors are also correlated with forest regeneration in anthropogenic environments, specifically temperature, nebulosity and air relative humidity.

regeneration depended on climate conditions (Figure 3). The highest NDVI was observed in the absence (Neutral) of the two phenomena, and the lowest NDVI was observed with the occurrence of El Niño. These correlations can be explained by the reduced rainfall in the state of Minas Gerais during El Niño and La Niña (MINUZZI et al., 2005; Minuzzi et al., 2007). In regions with marked dry and rainy seasons such as in the Cerrado, vegetation responds quickly to rainfall (GURGEL et al., 2003). In addition, the El Niño effect was observed to differentially affect Brazilian vegetation types independently of its intensity.
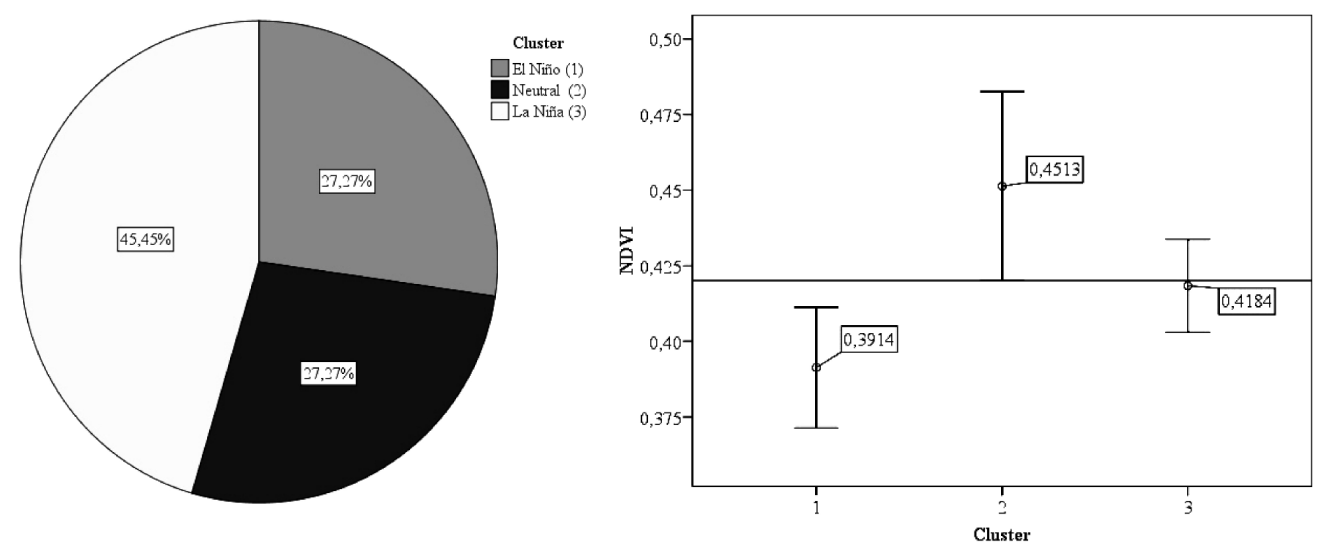

Figure 3. Cluster representativity on the dataset and NDVI variation within the clusters

The significance of the clusters to explain the observed NDVI patterns in the areas undergoing natural regeneration in the Cerrado was tested.
Statistical significance was observed for cluster 1 (El Niño) and cluster 2 (Neutral) (Figure 4). 


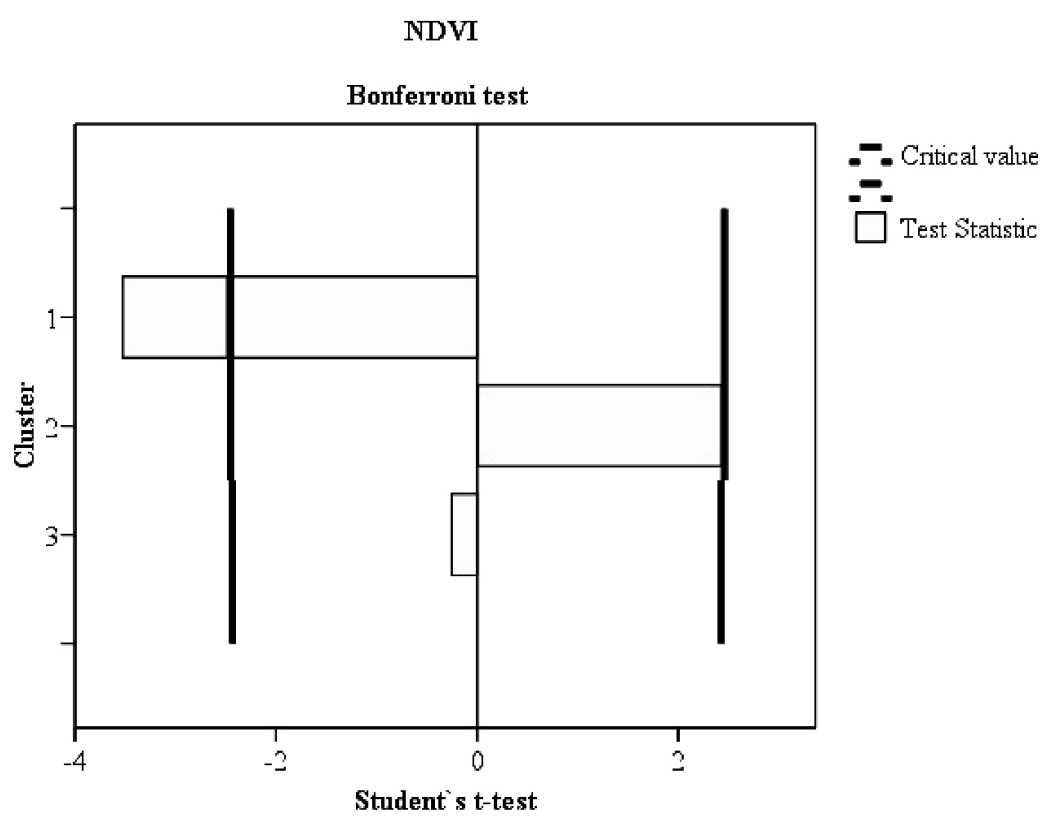

Figure 4. Two Step Cluster analysis.

The absence of El Niño and La Niña (Neutral) had a positive effect on NDVI, and the occurrence of El Niño had a negative effect, which was related to the resulting decreased rainfall in the study region (MINUZZI et al., 2005).

Vegetation dynamics in South America over the last few years have been associated with a significant decrease in rainfall and are affected by soil use, soil cover, topography and soil type (BARBOSA et al., 2015). The history of environmental degradation also explains variations in the natural regeneration dynamics in the Cerrado.

The influence of rainfall and the occurrence of El Niño and La Niña on the regeneration pattern of the Cerrado can be explained by the marked differences in the dry and rainy seasons in the environment where Cerrado is included. However, to analyse the dependence of natural regeneration on climate conditions (rainfall), the level of degradation of the anthropogenic environments must be better evaluated.

\section{CONCLUSIONS}

The dynamics of natural regeneration presents a growing pattern of forest cover over time when protected from recurrence of human actions the NDVI was an effective tool in the study of vegetation dynamics in the regenerating environments.

The natural regeneration process in anthropogenic environments in the Cerrado has a positive and significant correlation with rainfall, with greater influence of rainfall in the dry season;

The El Niño weather phenomenon influences negatively on the natural regeneration process in the Cerrado;

In the Cerrado, natural regeneration can be adopted as a tool with which to aid in the restoration of degraded areas and to build anthropogenic environments that possess the capacity for resilience.

RESUMO: No Cerrado a evidencia dos impactos ambientais são as grandes áreas homogêneas com pastagens e agricultura, com a presença de fragmentos florestais muito fragmentados e esparsos. Quando as áreas são abandonadas devido à baixa produtividade, inicia-se o processo de regeneração natural, com influência dos fatores ambientais. Assim, o objetivo desse estudo foi avaliar a dinâmica temporal da cobertura florestal em áreas antropizadas e a influência das condições climáticas no processo de regeneração natural no Cerrado. Para tanto, foi utilizada uma área antropizada protegida contra a entrada de animais domésticos e explorações agrícolas desde 2002. A identificação dos ambientes e a dinâmica do processo de regeneração natural foram obtidas por meio de imagens orbitais com o cálculo do índice de vegetação. A análise estatística não-paramétrica de Mann-Kendall foi utilizada para verificar a tendência da chuva e do Normalized Difference Vegetation Index, a análise multivariada para verificar as correlações e agrupamentos entre os anos de ocorrência de El Niño e La Niña e os valores do Normalized Difference Index. A dinâmica do processo de regeneração 
natural no Cerrado apresentou um padrão crescente em função do tempo e uma correlação positiva com a incidência de chuvas. O processo de recuperação de áreas degradadas pela técnica de regeneração natural mostrou se eficiente no Cerrado, no entanto, a regeneração natural é influenciada negativamente pelo fenômeno climático El Niño.

PALAVRAS-CHAVE: Savana. Índice de vegetação. Clima. Resiliência.

\section{REFERENCES}

ALMEIDA, R. O. P. O.; SANCHEZ, L. E. Revegetação de áreas mineração: critérios de monitoramento e avaliação do desempenho. Revista Árvore, Viçosa, v. 29, n. 1, p. 47-54, 2005. https://doi.org/10.1590/S010067622005000100006

ALLEN, R. G.; TASUMI M.; TREZZA, R.; WATERS. R.; BASTIAANSSEN. W. Surface energy balance algorithms for land (SEBAL). Advance training and users manual. Idaho, 2002. 98p.

BARBOSA, H. A.; LAKSHMI KUMAR, T. V.; SILVA, L.R.M. Recent trends in vegetation dynamics in the South America and their relationship to rainfall. Natural Hazards, Netherlands, v. 77, n. 2, p. 883-899, 2015. https://doi.org/10.1007/s11069-015-1635-8

BAYER, C.; MARTIN-NETO, L.; MIELNICZUK, J.; PAVINATO, A. Armazenamento de carbono em frações lábeis da matéria orgânica de um Latossolo Vermelho sob plantio direto. Pesquisa Agropecuária Brasileira, Brasília, v. 39, n. 7, p. 677-683, 2004. https://doi.org/10.1590/S0100-204X2004000700009

BECERRA, J. A. B.; SHIMABUKURO, Y. E.; ALVALÁ, R. C. S. Relação do padrão sazonal da vegetação com a precipitação na região do cerrado usando índices espectrais de vegetação. Anais, XIII Simpósio Brasileiro de Sensoriamento Remoto, Florianópolis, Brasil, INPE, p. 3747-3754, 2007.

BRAZ, A. J. B. P.; KLIEMANN, H. J.; SILVEIRA P. M. Produtividade de palhada de plantas de cobertura. In: SILVEIRA, P. M.; STONE, L. F (1 Ed). Plantas de cobertura dos solos do Cerrado. Embrapa Arroz e Feijão, p. 12-43, Santo Antonio de Goiás, Brasil. 2010.

CÂNDIDO, A. K. A. A; SILVA, N. M. da; BARBOSA D. S. Dinâmica espacial e temporal do uso do solo e índice de vegetação por diferença normalizada (NDVI) em setor de cabeceira do rio São Lourenço, Campo Verde, MT. Revista Ra'e Ga , Curitiba, v. 33, n. s, p. 94-119, 2015.

COUTINHO, F.; PEREIRA, M. G.; BEUTLER, S. J.; TORRES, J. L. R.; FABIAN, A. J. Avaliação das Limitações ao Uso Agrícola dos Solos da CEFET, Uberaba (MG). Anais, Manejo e conservação do solo e da água no contexto das mudanças ambientais, Rio de Janeiro, Brasil, p. 1-4, 2008.

DELGADO, R. C.; SEDIYAMA, G. C.; COSTA, M. H.; SOARES, V. P.; ANDRADE, R. G. Classificação espectral de área plantada com a cultura da cana-de-açúcar por meio da árvore de decisão. Engenharia Agrícola, Jaboticabal, v. 32, n. 2, p. 369-380, 2012. https://doi.org/10.1590/S0100-69162012000200017

DURIGAN, G.; MELO, A. C. G.; MAX, J. C. M.; BOAS. O. V.; CONTIERI, W. A.; RAMOS, V. S. Manual para recuperação da vegetação do Cerrado. $3^{a}$ ed. Revida e Atualizada. São Paulo: SMA, 2011. 19p.

GURGEL, H. C.; FERREIRA, N. J.; LUIZ, A. J. B. Estudo da variabilidade do NDVI sobre o Brasil, utilizando-se a análise de agrupamento. R. Bras. Eng. Agríc. Ambiental, Campina Grande, v. 7, n. 1, p. 85-90, 2003.

GRIMM, A. M.; BARROS, V. R.; DOYLE, M. E. Climate variability in Southern South America associated with El Niño and La Niña events. Journal of Climate, United States, v. 13, n. 1, p. 35-58, 2000.

https://doi.org/10.1175/1520-0442(2000)013<0035:CVISSA >2.0.CO;2 
INMET- Instituto Nacional de Meteorologia. Informações sobre as condições climáticas do município de Uberaba-MG. Disponível em:<http://www.inmet.gov.br>. Acesso em: 10 de set. 2015.

JACÓBSEN, L. O.; FONTANA, D. C.; SHIMABUKURO, Y. E. Efeitos associados a El Niño e La Niña na vegetação do estado do Rio Grande do Sul, observados através do NDVI/NOAA. Revista Brasileira de Meteorologia, São José dos Campos, v. 19, n. 2, p. 129-140, 2004.

KLINK, C. A.; MACHADO, R. B. Conservation of the Brazilian cerrado. Conservation biology, San Francisco v. 19, n. 3, p. 707-713, 2005. https://doi.org/10.1111/j.1523-1739.2005.00702.x

KÖPPEN, W. Climatologia: com um estudio de los clima de la tierra. México: Fondo de Cultura Economica, 1948. 478p.

LOPES, H. L.; CANDEIAS, A. L. B.; ACCIOLY, L. J. O.; SOBRAL, M. C. M.; PACHECO, A. P. Parâmetros biofísicos na detecção de mudanças na cobertura e uso do solo em bacias hidrográficas. R. Bras. Eng. Agríc. Ambiental, Campina Grande, v. 14, n. 11, p. 1210-1219, 2010.

MARKHAM, B. L.; BAKER, J. L. Landsat MSS and TM Post-Calibration Dynamix Ranges, Exoatmospheric Reflectances and At-Satellite Temperatures, Landsat Technical Notes, Lanham, v. 1, n. 1, p. 3-5, 1987.

MOHAMED, A. A. M.; BABIKER, I. S.; HIYAMA, T.; IKEDA, K.; KATO, K. Trends and variations in the activity of global vegetation in response to climate variability between 1987 and 1997. Sudan Journal of Science, Sudan, v. 6, n. 1, 2014.

MINUZZI, R. B.; SEDIYAMA, G. C.; COSTA, J. M. N.; VIANELLO, R. L. Influência da La Niña na estação chuvosa da região Sudeste do Brasil. Revista Brasileira de Meteorologia, São José dos Campos, v. 22, n. 3, p. 345-353, 2007. https://doi.org/10.1590/S0102-77862007000300008 https://doi.org/10.1590/S0102-77862007000300007

MINUZZI, R. B.; SEDIYAMA, G. C.; RIBEIRO, A.; COSTA, J. M. N. El Niño: ocorrência e duração dos veranicos do Estado de Minas Gerais. Revista Brasileira de Engenharia Agrícola e Ambiental, Campina Grande, v. 9, n. 3, p. 364-371, 2005. https://doi.org/10.1590/S1415-43662005000300011

MYERS, N.; MITTERMEIER, R. A; MITTERMEIER, C. G; FONSECA, G. A. B; KENT, J. Biodiversity hotspots for conservation priorities. Nature, London, v. 403, p. 853-858, 2000.

https://doi.org/10.1038/35002501

PAVANELLI, J. A. P.; GUIMARAES, E. Assessing the Dynamic of Structural Changes in Cerrado Vegetation of Protected and Non-Protected Areas using NDVI. International Journal of Advanced Remote Sensing and GIS, Delhi, v. 3, n. 1, p. 553-568, 2014.

PINHEIRO, E. S.; DURIGAN, G. Dinâmica espaço-temporal (1962-2006) das fitofisionomias em unidade de conservação do Cerrado no sudeste do Brasil. Revista Brasil. Bot., São Paulo, v. 32, n. 3, p. 441-454, 2009. https://doi.org/10.1590/S0100-84042009000300005

RESENDE, F. C.; SOARES, T. B. O.; SANTOS, P. R.; PEREIRA, G. Análise de Índices Espectrais para Estimativa de Áreas de Regeneração Florestal no Parque Nacional Chapada Das Mesas. Revista Territorium Terram, São João Del Rei v. 3, n. 5, p. 95-104, 2015.

ROUSE, J. W.; HASS, R. H.; SCHELL, J. A.; DEERING, D. W.; HARLAN, J. Monitoring the vernal advancement and retrogradation (green wave effect) of natural vegetation. College Station, Texas, v. 1, p. 1-8 1974.

ROUSE, J. W.; HAAS, R. H.; SCHELL, J. A.; DEERING, D. W. Monitoring vegetation systems in the Great Plains with ERTS. Third ERTS Symposium, NASA SP-351, Washington, v. 01, p. 309-317, 1973. 
SILVA, J. F.; FARINAS, M. R.; FELFILI, J. M.; KLINK, C. A. Spatial heterogeneity, land use and conservation in the Cerrado region of Brazil. Journal of Biogeography, Oxford, v. 33, n. 3, p. 536-548, 2006. https://doi.org/10.1111/j.1365-2699.2005.01422.x

TORRES, J. L. R.; FABIAN, A. J. Levantamento topográfico e caracterização da paisagem para planejamento conservacionista numa microbacia hidrográfica de Uberaba. Caminhos de Geografia, Uberlândia, v. 6, n. 19, p. 150-159, 2006. 